Leading article/Uvodnik

\title{
Professionalization of nursing in Slovenia: challenges and responsibilities for nurses with a higher education degree
}

\author{
Profesionalizacija zdravstvene nege v Sloveniji: izzivi in odgovornosti za visokošolsko \\ izobražene medicinske sestre in zdravstvenike
}

\author{
Brigita Skela-Savič
}

Fast-paced development of society and increasing needs for healthcare services call for a discussion on knowledge in nursing which could help meet these new demands. This leading article further develops some topics previously touched on in the leading article Professionalism in nursing: what is its current level in Slovenia (Skela-Savič, 2016a), adding new evidence from the project Nursing as a scientific discipline in Slovenia (Skela-Savič, et al., 2017a).

Based on my previous research work, I would describe the process of nursing professionalization as an organized system of formal higher education for an occupation with a strongly defined work ethic, responsibilities and code of conduct where its practitioners are members of a professional association. The work in performed on the basis of clearly defined guidelines and standards for monitoring work quality, self-monitoring, and evidence-based practice. The latter calls for a system of scientific research which provides new knowledge, assesses the appropriateness of existing practices, successfully addresses professional issues and needs of the society, and poses challenges for a new paradigm - in our case, the paradigm of nursing as a socially responsible scientific discipline and profession.

\section{Who is responsible for professionalization of nursing in Slovenia?}

A profession develops as the end result of the process of professionalization which is not a one-time event, but rather a series of development activities dependent primarily on the competencies of the highest-level decision makers, on their ability to strategically plan the implementation of changes and to clearly articulate the need for improvements in clinical practice to meet the needs of the healthy and ill populations. So-who is responsible for that? The answer lies in representative studies conducted in Slovenia (SkelaSavič, 2017; Skela-Savič, et al., 2016a, 2017a, 2017b). Nursing managers in healthcare institutions and longterm care facilities, managers in higher education institutions offering nursing programs, and managers of the national nursing association are the ones who should assume responsibility for the development of nursing at present and in the future.

The conditions for making the shift from an occupation to a profession include formally acquired knowledge, competencies, abilities, and values for development work in nursing as these can generate the understanding of development competencies and the implementation of evidence-based practice (Skela-Savič, et al., 2017b). In their employees, nursing managers must encourage the development of knowledge in research and evidence-based nursing care (Skela-Savič, et al., 2016a). By doing so, they will overcome the mentality identified in qualitative group interviews of experts in nursing which included, for example, understanding research and development as nurses' leisure activities, low self-awareness, a lack of interest for obtaining knowledge needed to establish research and development, and a lack of respect for research knowledge (Skela-Savič, 2017).

Current healthcare managers (including nurse leaders) must have obtained postgraduate-level managing and leadership skills as well as knowledge and competencies in the following areas: communication and relationship building, knowledge of the healthcare environment, modern approaches to leadership, establishment of

Associate Professor Brigita Skela-Savič, PhD, MSc, BSc, RN, Research Counsellor; Angela Boškin Faculty of Health Care, Spodnji Plavž 3, 4270 Jesenice, Slovenia

Correspondence e-mail/Kontaktni e-naslov: bskelasavic@fzab.si

The leading article is based on a submission by Brigita Skela-Savič entitled Slovenian nursing care and professionalization-challenges for the future, published in the journal commemorating the 90th anniversary of professional nursing association in Slovenia issued in 2017 in Ljubljana./Uvodnik je nastal na osnovi prispevka Brigite Skele-Savič Slovenska zdravstvena nega in profesionalizacija - izzivi za prihodnost, objavljenega v zborniku 90. let organiziranega delovanja v zdravstveni negi v Sloveniji, izšlega v Ljubljani leta 2017. 
professionalism at all levels, efficient system management, development of employees' knowledge and abilities needed to appropriately meet the needs in their environment, demographic trends, public health issues, establishment of values that support evidence-based practice, responsibility, quality and safety, intersectoral collaboration, implementation of the policy of constant quality monitoring and improvement, implementation of quality principles, and introduction of information technology solutions in healthcare, also in terms of improving work processes and ensuring active involvement of service users (American College of Healthcare Executives, 2014; Skela-Savič, 2016b). According to the American College of Healthcare Executives (2014), a specialization in nursing management is required for top nursing positions, yet no such requirement exists in Slovenia. With this in mind, it is easier to understand research findings that reveal successful professionalization of nursing in Slovenia. Skela-Savič and colleagues (2016a) have found that managers need a clear vision of development in research and evidence-based practice which is an integral part of the hospital's operations. To achieve that, they must develop nurse leaders whose job is to foster a culture of research and evidence-based practice in the clinical settings.

Also, we must reconsider the currently established practice in Slovenia that, when nurses with a higher education get promoted to head nurses, they stop being involved in direct patient care. Does that truly benefit the development of the profession? A comparison with physicians reveals that, when they get promoted to directors, medical directors or heads of major departments, they always retain some of their work in the clinical setting. Therefore, they do not face difficulties when it comes to understanding the clinical setting, being a part of it and returning to the clinical setting after the leadership position term ends. The practice common among nursing managers-that after assuming a leadership position they cut their ties with the clinical setting-is actually debilitating for the profession, possibly deterring the formation of a competitive arena for leadership and development positions, discouraging education at the second and third cycles, and neglecting those with a postgraduate degree who are not given an opportunity to transfer their knowledge into practice. This policy can be destructive and is detrimental for nursing as a profession. Actually, nursing managers should stay involved in clinical work, applying the tools of matrix organizational structure and transformational leadership in nursing and increasing the competencies of lower-level managers.

\section{Knowledge and competencies in nursing}

Extant research (Skela-Savič, et al., 2016b; 2016c; 2017a) clearly shows that nursing professionals in Slovenia have difficulties when it comes to the basic understanding and implementation of the first phase of professionalization, namely "the formation of profession", as termed by Watkins (2011), because they do not understand nursing competencies according to educational levels. Although competencies from secondary school nursing programs are not repeated in higher education nursing programs, the reality of clinical practice reveals a different picture. In fact, competencies for specialist work and for advanced practice in clinical settings, as outlined by the European Federation of Nurses Associations (EFN Workforce Committee, 2014), do not yet exist in Slovenia.

Moreover, research (Skela-Savič, et al., 2016b; 2016c; 2017a) conducted as part of a two-year project has indicated a host of issues, such as education-related differences and mistrust among secondary schools and higher education institutions, or the still prevalent belief that a secondary school degree in health care is required for enrollment into higher education nursing programs, despite the fact that a European Directive (Directive 2013/55/EU of the European Parliament and of the Council, 2013) unambiguously defines the requirement for enrollment as having completed 12 years of general education. Such attitudes are hindering the development of university programs which earn graduates the professional title registered nurse (RN). After all, all European Union (EU) member countries and most former Yugoslavian countries committed to developing these programs. A four-year education at the university level would better equip graduates with the knowledge necessary for understanding and implementing nursing professionalization.

Finally, the system of continuous professional education-a condition for obtaining a nursing license-is in need of reform. It has been shown that Slovenian nurses holding a higher education degree receive very little education in applied research, development work and evidence-based practice (Skela-Savič, et al., 2016a). The obligatory programs for a nursing license have to be expanded to include the understanding of ethics not only in terms of responsibility towards the patients and long-term care residents, but also in terms of responsibility for the development of the profession-that is what nursing care should be like, but it is sadly not. Obligatory educational programs should also include evidencebased practice.

\section{Patient needs and human resource requirements}

It has to be carefully considered which knowledge and skills nurses need to meet current patient needs and how human resource requirements should be set to ensure enough patient time and an acceptable quality and safety of patient work. For the past decade, higher education system has produced masters in nursing, but advanced practice positions in healthcare institutions 
have yet to be systematized although the needs for these positions already exist. Good examples are family medicine reference clinics (FMRCs). Nurses with a higher education degree employed at these clinics are included in postgraduate education modules planned by family physicians. However, these modules are not accredited and therefore do not earn them a higher level of education. According to the ICN guidelines, nurses working in advanced practice should have a master's degree. When we come across the fruits of labor by RNs employed at FMRCs published by family physicians in international and Slovenian journals, these nurses are rarely credited as co-authors and their position is stated as advance nurse practitioner. That is the case in articles, but a master's degree is not a requirement for their position in practice. What is more, few community health centers support RNs working in FMRCs in their efforts to obtain a master's degree in nursing of health promotion.

Evidence-based results must be presented to underline the need for more nursing professionals with a higher education degree. As part of nursing development nursing, nurses should go on strike as a unified occupational group and demand that human resource requirements be increased, that European directives be followed in practice, and that the level of education in nursing be raised, as these measures would lead to a decrease in complications which come with a price. There is more than enough evidence to support these demands. The most recent study by Aiken and colleagues (2017) revealed that, if a nursing team consists of four nurses with a higher education degree and two nurses with a lower education and cares for 25 surgical patients, substituting one nurse with a higher education for a nurse with a lower education increased the patients' odds of dying by $21 \%$. The study was conducted in Belgium, England, Spain, Switzerland and Finland. And how many nurses with a higher education degree care for 25 surgical patients in Slovenia? After considering this question, we can no longer claim that Slovenian nurses will never go on strike, but we should rather say that they must strike-by doing so, we take the right ethical stance for the provision of high-quality, safe nursing care. A strike would let patients know that they could receive better care if our conditions were similar to those in other countries and if work standards for nurses were comparable to those of physicians.

Slovenia is at the bottom of EU member countries in the percentage of nurses with a higher education degree (OECD, 2013). It is not enough that only a few members of the higher education arena are drawing attention to the fact that although Slovenia's educational system is in line with the European directive for regulated professions, this is not reflected in human resource requirements only in the field of nursing, unlike in medicine, dentistry, midwifery, pharmacy, veterinary medicine, and architecture. After 90 years of existence, RNs are still not the predominant nursing care providers in Slovenian clinical settings. Most nursing care is still conducted by assistant nurses who lack the necessary level of education and professional competencies for the scope and level of difficulty of the work they conduct. In reality, nursing managers drive assistant nurses into exceeding their professional competencies on a daily basis (Skela-Savič, et al., 2016c) by failing to employ enough RNs. Who is responsible for this situation? The answer is provided in a research report by Skela-Savič and colleagues (2017a) - the fact that assistant nurses are exceeding their competencies due to a lack of nurses with a higher education degree was created within the nursing profession itself. An interesting research question therefore emerges: what would the study by Aiken and colleagues (2017) reveal if it was conducted in Slovenia?

The study conducted by Albreht (2005) projects the need for more higher education nursing programs by taking into account only the demographic data for nurses with a higher education degree without considering patient needs. When Slovenia acceded to the EU and the Directive for regulated professions was implemented, nursing managers, higher education managers and the Nurses and Midwives Association of Slovenia (NMAS) failed to explain, based on international research evidence, that the number of higher education nursing programs must be increased and the number of secondary school nursing programs decreased as even then many assistant nurses faced unemployment. Moreover, a divergence began to be seen between nurses with a secondary school degree and a higher education degree when Slovenia entered the EU, and that divergence continues to be felt and is hindering the development of nursing as a profession. We continue to focus on the fifth and seventh levels according to the Slovenian Qualifications Framework, while patient needs call for specialist nurses, masters in nursing, and doctors of nursing practice. Today, Slovenia no longer faces a lack of nurses with a higher education degree; the issue today is that there are not enough systematized positions for these nurses. Systematization of four categories of practitioners (EFN Workforce Committee, 2014) with clearly defined competencies is sorely needed.

\section{Professional title after completed formal education}

Another issue related to professionalization of nursing in Slovenia concerns the professional title of this occupational group. The project Nursing as a scientific discipline (Skela-Savič, et al., 2016c) revealed that the term caregiver has low social status, being perceived as less worthy and as such being inappropriate for a nursing care practitioner. In addition, the representatives of secondary healthcare schools did not embrace some new areas of nursing work, such as long-term care. Since 2007, there has been an ongoing debate about the professional title for nurses with a higher education degree which would 
clearly illustrate the nature of work they conduct. In the last decade, the Slovenian Board for Nursing (SBN) has adopted a different title for this occupational group twice, most recently in 2014 when the adopted title was 'health care practitioner'. This represents only a minor change since this title ('zdravstvenik') has been in use for male nurses since 2004. The Ministry of Health has not yet implemented this proposal by placing it on the list of healthcare professions.

Discussions on the need to rename the professional title have sparked and continue to spark objections. A frequently heard reasoning is that the existing title, 'medical nurse' ('medicinska sestra), is accepted in Slovenia and there is no need to change it. These arguments show a lack of understanding for the concept of professionalization. After all, even Angela Boškinthe first Slovenian nurse with a higher education degree-had the title 'care nurse' and not 'medical nurse'. As the occupation of nursing undergoes the process of professionalization, we should think about whether the professional title of Slovenian nurses is appropriate for usage of today and tomorrow. Decades ago, medical schools in Slovenia were renamed into healthcare schools, while the professional title of female nurses still holds the word 'medical'. No matter how we try to find evidence in an effort to understand why the professional title cannot be changed, one conclusion can be drawn: caring as the essence of the nursing profession has not been researched enough to withstand expert judgment, in nursing and outside of it, that it is also science. And that is the key problem with nursing as a scientific discipline, if compared to medicine. Both nursing theory and practice have to be developed and compared. We have to stop with the division of theoretical discourse in schools and practical knowledge in the clinical setting.

According to Carvalho (2014), healthcare professions differ from each other primarily in knowledge obtained through research work. Some nurses perceive this new knowledge as a deviation from nursing care and rather opt to support the local context of knowledge in practice. Horton and colleagues (2007) claim that, from a historical perspective, nursing entails the basic tasks of caring for and helping the ill and their families. At the moment, the profession is caught between the provision of care which was historically practiced by less educated 'caregivers' or those who acquired the knowledge, and nursing as a science which is-or should be-practiced by nurses with a higher education degree. Why is the proposed professional title 'graduated nursing practitioner' unacceptable if the occupation is termed nursing care?

\section{Challenges for the future}

Several years of research work went into defining, at the strategic level, the national responsibility for the development of nursing as a scientific discipline and the indicators of whether national responsibility is being fulfilled (Skela-Savič, 2017), and the results are published in this issue of the Slovenian Nursing Review. Fulfilling the national responsibility for achieving progress in professionalization of nursing is of utmost importance and must become the priority in the national strategy of nursing development in Slovenia. The defined national responsibility can be fulfilled by responsible managers who possess the knowledge and skills needed to recognize resources and opportunities for meeting the indicators for fulfilling the national responsibility. The goal is professionalization of nursing for high-quality, safe and efficient health care provision. The tools for reaching this goal include systematic research, expert judgment, development of critical thinking, and evidence-based decision making.

The efforts to make research work in nursing established can only be realized through a national institute for research work in nursing which must be founded by the NMAS. It is not reasonable to wait that nursing receives support from other institutions on this issue, especially regarding the current state of healthcare policy in Slovenia. The institute should be funded from membership fees of NMAS members and from calls for application. Such a national research institute will have an 'evidence-based' influence on politics; once it becomes scientifically established, it can obtain public funding for its operations. The institute should follow the maxim expressed in the previously mentioned study: "The center of development and research work must be the patient" (Skela-Savič, 2017).

Our professional association is celebrating 90 years of its existence. The national professional association (NMAS) is facing a special challenge: it has to formulate an ambitious and modern vision of development and set down its goals and the strategy for achieving them. A clear vision of development which supports social responsibility and responds to the needs of society calls for a systematic division of funding, a reflection on the current structure, and allocation of funding for research and development. It is crucial to demand a transparency of operations both at the level of the Association and at the level of regional societies. Professional associations must become the engine of professionalization, advocating evidence-based practice and research work. At the level of the national association, a clear distinction between the profession and politics must exist because only nonpartisanism will enable it to function in an evidence-based manner regardless of the political party in power. This is not to say that political activation of nursing professionals is undesired-on the contrary-, but it should take the form of candidacy in national and regional elections.

\section{Final thoughts}

As an expert and researcher in nursing and health care, I wish to convey the following message: the development 
of nursing as a profession and a scientific discipline is becoming increasingly dependent on how it is perceived within the occupational group. There are two distinct dimensions of perceiving nursing which have to coincide-the scientific dimension of nursing care provision and the dimension of reflection on nursing practice. The first provides nurses with a higher education degree with new knowledge to be tested in practice, while the second must serve as an imperative to researchers for scientific investigation and be categorized either in the field of nursing knowledge or, conversely, in the field of non-evidence-based practice. To achieve the latter, every $\mathrm{RN}$ must possess the necessary knowledge to understand the importance of research resulting in scientific findings. RNs should support development work in nursing and contribute to the exchange of evidence and findings from practice. That is how nursing will be able to retain the values which have historically shaped its relation to the healthy and the ill, and add the values of scientific knowledge on nursing care, professional development and evidence-based practice. Such a compromise is beneficial, enabling theory and practice to merge into one. A combination of these two dimensions will solidify the position of nursing as a profession and a scientific discipline providing care based on scientific evidence. If nurses with a higher education degree will fail to undertake this task, nursing will become a peripheral supporting service of the healthcare system and get lost in a myriad of those who, in the increasing needs for health and health care provision, will seize the opportunity and become advocates for the needs of the healthy and ill populations. Therefore, we cannot afford to waste time on unproductive squabbles and reproaches on excessive ambitiousness of individuals proposing changes. Instead, we should come together and scientifically substantiate our work-nursing care provision-as was done previously by our forerunners, Florence Nightingale and Angela Boškin, according to the level and understanding of the occupation at the time.

\section{Slovenian translation/Prevod $v$ slovenščino}

Dinamičen družbeni razvoj in večanje zahtev po zdravstvenih storitvah zahtevata razpravo o znanju $\mathrm{v}$ zdravstveni negi, kakršno bi bilo tem novim zahtevam kos. Pričujoči uvodnik nadaljuje teme, začete že v uvodniku Professionalism in nursing: what is its current level in Slovenia (Skela-Savič, 2016a), in dodaja nova spoznanja iz projekta Zdravstvena nega kot znanstvena disciplina v Sloveniji (Skela-Savič, et al., 2017a).

$\mathrm{Na}$ osnovi dosedanjega lastnega raziskovalnega dela bi pot profesionalizacije stroke zdravstvene nege opisala kot urejen sistem formalnega visokošolskega izobraževanja za poklic, ki ima opredeljeno poklicno etiko in odgovornost ter kodeks delovanja, izvajalce določene stroke pa povezuje profesionalno združenje. Podlage za poklicno delo so izdelane smernice in standardi za spremljanje kakovosti dela, vzpostavljen nadzor lastnega dela in $\mathrm{z}$ dokazi podprto strokovno delo. Delo, podprto $\mathrm{z}$ dokazi, zahteva tak sistem znanstvenega raziskovanja, ki prinaša nova znanja, potrjuje ustreznost ali neustreznost obstoječega delovanja $\mathrm{v}$ stroki, odgovarja na probleme $\mathrm{v}$ stroki in na družbene potrebe ter postavlja izzive za novo razvojno paradigmo, $v$ našem primeru za paradigmo zdravstvene nege kot družbeno odgovorne znanstvene discipline in profesije.

\section{Odgovorni za profesionalizacijo zdravstvene nege $v$ Sloveniji}

Profesija se razvije v procesu profesionalizacije, ki ni enkratno dejanje, temveč je niz razvojnih aktivnosti, ki so odvisne predvsem od usposobljenosti odgovornih na najvišjih pozicijah odločanja, od njihove sposobnosti strateškega načrtovanja sprememb in argumentiranega izražanja zahtev za izboljšave pri delu, s katerimi lahko odgovorimo na potrebe zdravih in bolnih. Kdo so torej odgovorni? Odgovor temelji na v Sloveniji izvedenih reprezentativnih raziskavah (Skela-Savič, 2017; SkelaSavič, et al., 2016a, 2017a, 2017b). Menedžment zdravstvene nege zdravstvenih in socialnih zavodov, menedžment visokošolskih zavodov s študijskimi programi zdravstvene nege in menedžment nacionalnega združenja $\mathrm{v}$ zdravstveni negi so tisti, ki morajo prevzeti odgovornost za razvoj zdravstvene nege danes in $\mathrm{v}$ prihodnosti.

Za premik, da se stroka razvije v profesijo, so potrebni formalnopridobljenoznanje, kompetence, sposobnosti in vrednote za razvojno delo $\mathrm{v}$ zdravstveni negi, ki lahko generirajo razumevanje razvojnih kompetenc in uresničevanje $\mathrm{z}$ dokazi podprtega dela (Skela-Savič, et al., 2017b). Menedžment zdravstvene nege mora pri zaposlenih podpreti razvoj znanj iz raziskovanja in znanj z dokazi podprte zdravstvene nege (Skela-Savič, et al., 2016a). S tem bo presežena miselnost, ki smo jo prepoznali $\mathrm{v}$ kvalitativnih skupinskih intervjujih strokovnjakov zdravstvene nege, npr. opredeljevanje raziskovanja in razvoja kot prostočasnih aktivnosti medicinskih sester, nizko lastno zavedanje in nizek interes za pridobivanje znanj za vzpostavitev raziskovanja in razvoja, nizko spoštovanje znanja o raziskovanju (Skela-Savič, 2017).

Menedžerji $\mathrm{v}$ zdravstvu (mednje sodijo tudi vodilni v zdravstveni negi) morajo dandanes imeti na podiplomskih izobraževanjih pridobljene sposobnosti za upravljanje in vodenje ter znanja in kompetence za naslednja področja: komunikacija in gradnja odnosov, znanje o zdravstvu in okolju, sodobni pristopi v vodenju, izgradnja profesionalizma na vseh ravneh, učinkovito upravljanje sistema, razvoj znanj in sposobnosti pri zaposlenih za ustrezen odziv na potrebe okolja, demografski trendi, javnozdravstveni problemi, izgradnja vrednot, ki podpirajo $\mathrm{z}$ dokazi podprto delo, odgovornost, kakovost in varnost, 
medsektorsko povezovanje, udejanjanje politike nenehnega spremljanja in izboljševanja kakovosti ter udejanjanje načel kakovosti, uvajanje informacijske tehnologije $\mathrm{v}$ zdravstvu tudi $\mathrm{z}$ vidika izboljševanja procesov dela in aktivne vključenosti uporabnikov storitev (American College of Healthcare Executives, 2014; Skela-Savič, 2016b). Ameriško združenje izvršnih direktorjev $\mathrm{v}$ zdravstveni negi (American College of Healthcare Executives, 2014) pravi, da mora biti specializacija iz menedžmenta zdravstvene nege obvezna za prevzem vodilnih delovnih nalog, vendar v Sloveniji teh pogojev nimamo. Zato je lažje razumeti tudi nekatera spoznanja raziskav, ki kažejo na uspešnost profesionalizacije zdravstvene nege $\mathrm{v}$ Sloveniji. Skela-Savič in sodelavci (2016a) ugotavljajo, da mora menedžment prispevati jasno razvojno vizijo raziskovanja in $\mathrm{z}$ dokazi podprto delo $\mathrm{v}$ zdravstveni negi, ki je umeščena $\mathrm{v}$ delovanje celotne bolnišnice. $\mathrm{V}$ ta namen morajo razvijati vodilne medicinske sestre/ zdravstvenike, katerih naloga je oblikovanje kulture raziskovanja in $\mathrm{z}$ dokazi podprtega dela $\mathrm{v}$ kliničnih okoljih.

Zamisliti se je treba tudi nad uveljavljeno prakso $\mathrm{v}$ Sloveniji, da ko visokošolsko izobražena medicinska sestra/zdravstvenik postane glavna medicinska sestra/ zdravstvenik, izgubi stik $\mathrm{z}$ neposrednim delom pri pacientu. Ali je to $\mathrm{v}$ korist razvoja profesije? Naj to primerjamo z zdravniki, le-ti, ko postanejo generalni ali strokovni direktorji ali predstojniki večjih klinik, vedno ohranijo del svojega strokovnega dela $\mathrm{v}$ kliničnem okolju. Zato nikoli nimajo problemov, da kliničnega okolja ne bi razumeli, da ne bi bili del njega in da se po končanem mandatu ne bi vrnili v klinično okolje, iz katerega so prišli na vodilno delovno mesto. Praksa menedžmenta zdravstvene nege, da po prevzemu vodilne funkcije posameznik ne deluje več v kliničnem okolju, slabi profesionalizacijo, saj lahko pride do zavor pri ustvarjanju konkurenčne arene za vodilna in razvojna delovna mesta, zaviranja izobraževanj na drugi in tretji bolonjski stopnji in spregleda tistih, ki končajo študij na drugi ali tretji bolonjski stopnji in ne dobijo priložnosti za prenos znanj v prakso. Taka politika je lahko destruktivna in zdravstveni negi škodi. Menedžment zdravstvene nege naj ostane vključen $\mathrm{v}$ strokovno delo, pri tem naj uporabi orodja matrične organizacijske strukture in transformacijskega vodenja zdravstvene nege, poveča naj pooblaščanje vodilnih na nižjih nivojih vodenja.

\section{Znanje in kompetence $v$ zdravstveni negi}

Raziskave (Skela-Savič, et al., 2016b, 2016c, 2017a) zelo jasno pokažejo, da imamo v slovenski zdravstveni negi probleme $\mathrm{v}$ temeljih razumevanja in uresničevanja prve faze profesionalizacije, torej pri »oblikovanju profesije«, kot je fazo poimenovala Watkins (2011), saj imamo težave pri razumevanju kompetenc $\mathrm{v}$ zdravstveni negi glede na ravni izobraževanja za poklic. Res je, da se kompetence srednješolske ravni izobraževanja ne podvajajo na visokošolskem izobraževanju iz zdravstvene nege, realnost v praksi pa je popolnoma drugačna. Kompetenc za specialistično delo in za napredne oblike dela v kliničnih okoljih po zgledu evropskega združenja v zdravstveni negi (EFN Workforce Committee, 2014) v Sloveniji namreč še ni.

Tudi raziskave (Skela-Savič, et al., 2016b, 2016c, 2017a) v okviru dvoletnega projekta opozarjajo na številne probleme, od tega, da med srednjimi šolami in visokošolskimi zavodi prihaja do razhajanj in nezaupanja glede izobraževanja, do tega, da je še vedno prisotna miselnost, da je za vstop v visokošolsko izobraževanje potrebna srednješolska izobrazba zdravstvene smeri, kljub temu da evropska direktiva (Directive 2013/55/EU of the European Parliament and of the Council, 2013) jasno opisuje pogoje za vstop v izobraževanje, to je zaključeno dvanajstletno splošno izobraževanje. Takšna stališča onemogočajo razvoj univerzitetnih (UN) študijskih programov za pridobitev strokovnega naslova diplomirana medicinska sestra/zdravstvenik (UN), h katerim so pristopile vse evropske države in tudi večina držav bivše Jugoslavije. Univerzitetno izobraževanje, ki bi trajalo štiri leta, bi diplomante bolje opremilo z znanji za razumevanje in uresničevanje profesionalizacije zdravstvene nege.

Potrebna je tudi prenova kontinuiranega profesionalnega izobraževanja, ki je pogoj za pridobitev licence. Vemo, da se visokošolsko izobražene medicinske sestre/ zdravstveniki zelo malo izobražujejo iz aplikativnega raziskovanja, razvojnega dela in $z$ dokazi podprtega dela (Skela-Savič, et al., 2016a). V obveznem izobraževanju za licence je potrebna nadgradnja vsebin, kot je razumevanje etike ne samo v dimenziji odgovornosti do pacienta in varovanca, temveč tudi v dimenziji odgovornosti za razvoj stroke - takšna bi zdravstvena nega namreč morala biti, pa žal ni. Del vsebin obveznega izobraževanja mora postati tudi z dokazi podprta zdravstvena nega.

\section{Potrebe pacientov in kadrovski normativi}

Razmisliti je treba, kakšno bi moralo biti naše znanje glede na potrebe, ki jih imajo pacienti danes, in kakšni bi morali biti kadrovski normativi, da bi bilo delo $s$ pacientom humano in na sprejemljivi ravni kakovosti in varnosti. Visokošolski sistem že 10 let izobražuje magistrice in magistre zdravstvene nege, pa delovna mesta za napredne oblike dela $\mathrm{v}$ zdravstvenih zavodih še danes niso sistematizirana, potrebe po njih pa so. Lep primer so referenčne ambulante družinske medicine (RADM). Visokošolsko izobražene medicinske sestre/ zdravstveniki, ki delajo v RADM, imajo podiplomsko izobraževanje, ki so ga pripravili zdravniki družinske medicine. Toda to podiplomsko izobraževanje ni akreditirano in jim ne prinese dviga stopnje izobrazbe. Usmeritev Mednarodnega sveta medicinskih sester 
(International Council of Nurses - ICN) pa je, da je za napredne oblike dela potreben strokovni magisterij. Ko danes prebiramo rezultate dela diplomiranih medicinskih sester/zdravstvenikov v RADM, ki jih v člankih objavljajo specialisti družinske medicine, in to $\mathrm{v}$ mednarodnih in domačih revijah, je soavtorstvo diplomiranih medicinskih sester/zdravstvenikov prisotno le izjemoma, njihovo delo pa je opisano kot advance nurse practitioner. Tako $\mathrm{v}$ člankih, realno pa za zasedbo delovnega mesta strokovni magisterij ni pogoj. Še več, redki so zdravstveni domovi, ki diplomirane medicinske sestre/zdravstvenike v RADM podprejo pri magistrskem študiju zdravstvene nege ali promocije zdravja.

$\mathrm{Z}$ dokazi podprto je treba povedati, da potrebujemo več visokošolsko izobraženega kadra. V okviru procesa razvoja profesije bi danes medicinske sestre/ zdravstveniki morali stavkati kot enovito poklicno telo in to za dvig kadrovskih normativov, za upoštevanje evropskih direktiv $\mathrm{v}$ praksi in dvig stopnje izobrazbe $\mathrm{v}$ zdravstveni negi, saj navedeno pomeni manj zapletov v zdravstveni obravnavi, vsak zaplet pa ima svojo ceno. Za takšno držo imamo dovolj dokazov. Zadnja raziskava Aiken in sodelavcev (2017) kaže, da če v timu zdravstvene nege, ki skrbi za 25 kirurških pacientov in ga sestavljajo štiri visokošolsko izobražene medicinske sestre/zdravstveniki in dva manj izobražena izvajalca zdravstvene nege, nadomestimo eno visokošolsko medicinsko sestro/zdravstvenika $\mathrm{z}$ manj izobraženim izvajalcem zdravstvene nege, verjetnost za smrtnost pacientov povečamo kar za $21 \%$. Raziskava je potekala v Belgiji, Angliji, Španiji, Švici in na Finskem. Koliko visokošolsko izobraženih medicinskih sester/ zdravstvenikov na 25 kirurških pacientov pa imamo mi? Po takšnem premisleku ne bomo več izjavljali, da medicinske sestre/zdravstveniki ne bodo nikoli stavkali, ampak bomo rekli, da medicinske sestre/ zdravstveniki morajo stavkati, ker s tem zavzamemo pravilno etično držo za izvajanje kakovostne in varne zdravstvene nege. Stavka bi paciente opozorila, da bi zanje lahko bolje skrbeli, če bi imeli vzpostavljene mednarodno primerljive pogoje in take standarde dela, kot jih zahtevajo tudi zdravniki.

Slovenija je na repu držav Evropske unije (EU) po deležu visokošolsko izobraženih medicinskih sester/ zdravstvenikov (OECD, 2013). Zato ni dovolj, da le redki predstavniki visokošolskega prostora opozarjajo na dejstvo, da država Slovenija sicer izobražuje po evropski direktivi za regulirane poklice, da pa izključno za področje zdravstvene nege zapisanega ne prevede $\mathrm{v}$ kadrovske normative, medtem ko to upošteva pri zdravnikih, zobozdravnikih, babicah, farmacevtih, veterinarjih in arhitektih. Dejstvo po 90 letih delovanja je, da diplomirane medicinske sestre/ zdravstveniki niso večinski izvajalci zdravstvene nege $\mathrm{v}$ kliničnih okoljih. Največji del zdravstvene nege izvajajo srednješolsko izobraženi tehniki/-ice zdravstvene nege, ki pa za izveden obseg in zahtevnost dela nimajo ustrezne stopnje izobrazbe in poklicnih kompetenc. Situacija je namreč taka, da menedžment zdravstvene nege tehnike/-ice zdravstvene nege sili $\mathrm{v}$ dnevno preseganje poklicnih kompetenc (SkelaSavič, et al., 2016c), saj ne zaposli dovolj diplomiranih medicinskih sester/zdravstvenikov. Odgovornost za takšno situacijo lahko razberemo iz raziskovalnega poročila Skele-Savič in sodelavcev (2017a), saj smo si stanje preseganja kompetenc tehnikov/-ic zdravstvene nege zaradi pomanjkanja visokošolsko izobraženih medicinskih sester/zdravstvenikov, ustvarili znotraj stroke sami. Postavi se raziskovalno vprašanje, kaj bi pokazala raziskava Aiken in sodelavcev (2017), če bi jo izvedli v Sloveniji?

Albreht (2005) jasno napoveduje potrebo po povečanju izobraževanja na visokošolski ravni, kjer upošteva le demografske podatke o populaciji visokošolsko izobraženih medicinskih sester in ne potreb pacientov. Menedžment zdravstvene nege in visokošolski menedžment ter Zbornica - Zveza $\mathrm{v}$ trenutkih vstopa v EU in pri implementaciji evropske direktive za regulirane poklice niso bili dovolj uspešni, da bi na osnovi spoznanj tujih raziskav pojasnili, da je ob vstopu v EU treba povečati obseg izobraževanja na visokošolski ravni in zmanjšati obseg izobraževanja na srednješolski ravni, saj je že takrat bila očitna brezposelnost tehnikov/-ic zdravstvene nege. Še več, po vstopu v EU je prišlo do razhajanj med skupinama srednješolsko in visokošolsko izobraženih medicinskih sester/zdravstvenikov, ki jih čutimo še danes. Le-ta ovirajo razvoj zdravstvene nege kot profesije in še danes se ukvarjamo izključno s peto in sedmo ravnjo izobraževanja glede na slovensko ogrodje kvalifikacij, potrebe pacientov pa so takšne, da $\mathrm{v}$ kliničnem delu potrebujemo specialiste/-ke, magistre/-ice in doktorje/-ice zdravstvene nege. Danes v Sloveniji ni problem pomanjkanja visokošolsko izobraženih medicinskih sester/zdravstvenikov, temveč premajhno število sistematiziranih delovnih mest za visokošolsko izobražene medicinske sestre/zdravstvenike. Potrebna je sistematizacija štirih kategorij izvajalcev (EFN Workforce Committee, 2014), ki imajo jasno opredeljene kompetence.

\section{Strokovni naslov po zaključenem formalnem izobraževanju}

Težave pri profesionalizaciji zdravstvene nege $\mathrm{v}$ Sloveniji se kažejo tudi v strokovnem naslovu za poklic. Projekt Zdravstvena nega kot znanstvena disciplina (Skela-Savič, et al., 2016c) pokaže, da izobrazbeni naslov negovalec/negovalka nima statusa in se ga šteje kot manj vredno in neprimerno poimenovanje za izvajalce zdravstvene nege. Tudi prepoznavanje novih področij delovanja, kot je dolgotrajna oskrba, ni sprejeto $s$ strani predstavnikov srednješolskega sektorja. $\mathrm{O}$ visokošolskem strokovnem naslovu, ki bi jasno poimenoval vsebino dela pri opravljanju tega poklica, 
razprave potekajo že od leta 2007. V zadnjih desetih letih je Razširjeni strokovni kolegij za zdravstveno nego (RSKZN) že dvakrat potrdil spremembo strokovnega naslova, nazadnje leta 2014, ko je bil sprejet strokovni naslov diplomirana zdravstvenica/zdravstvenik, ki je blaga oblika preimenovanja, saj je le-ta za moški spol v uporabi že od leta 2004 naprej. Do realizacije predloga na strani Ministrstva za zdravje, ki mora predlog RSKZN umestiti $\mathrm{v}$ seznam poklicev $\mathrm{v}$ zdravstvu, še ni prišlo.

Ob razpravah o spremembi strokovnega naslova je bilo in je še veliko nasprotovanj, tudi z utemeljevanjem, da je naslov medicinska sestra $v$ Sloveniji sprejet in da ga ni treba spreminjati. To kaže na nerazumevanje profesionalizacije. Nenazadnje si je že Angela Boškin pridobila strokovni naslov skrbstvena sestra in ne medicinska sestra. $V$ fazi profesionalizacije mora stroka premišljevati tudi o tem, ali je strokovni naslov poklica ustrezen za rabo danes in v prihodnosti. Že desetletja nazaj so se medicinske šole preimenovale $\mathrm{v}$ zdravstvene šole, naslov poklica pa za žensko poimenovanje še vedno v sebi nosi "medicino«. Kakorkoli iščemo dokaze za razumevanje, zakaj spremembe strokovnega naslova ni mogoče izvesti, lahko zaključimo, da negovanje kot osrednja esenca profesije še ni raziskano dovolj, da bi prestalo profesionalno presojo znotraj in izven zdravstvene nege, da gre tudi pri negovanju za znanost. To je ključni problem zdravstvene nege kot znanstvene discipline, če le-to primerjamo $\mathrm{z}$ medicino. Potrebni sta izoblikovanje in primerjava teorije in prakse zdravstvene nege. Treba je prenehati $\mathrm{z}$ diskurzom teoretičnega znanja $\mathrm{v}$ šoli in praktičnega znanja v kliničnem okolju.

Carvalho (2014) ugotavlja, da profesije v zdravstvu med seboj najbolj loči znanje, pridobljeno $\mathrm{z}$ raziskovalnim delom. Nekatere medicinske sestre/ zdravstveniki to novo znanje zaznavajo kot odmik od negovanja in podpirajolokalni kontekst znanja v praksi. Horton in sodelavci (2007) pravijo, da zdravstvena nega zgodovinsko gledano vključuje temeljne naloge negovanja in pomoči bolnim in svojcem. Profesija se tako nahaja med izvajanjem nege in skrbi, ki so jo zgodovinsko izvajale manj izobražene ali priučene "sestre", in negovanjem kot znanostjo, ki jo izvajajo oz. bi jo morale izvajati visokošolsko in akademsko izobražene medicinske sestre/zdravstveniki. Zakaj se ne strinjamo s predlogom diplomirana zdravstvena negovalka/negovalec, če se stroka imenuje zdravstvena nega?

\section{Izzivi za prihodnost}

$Z$ večletnim raziskovalnim delom smo na strateški ravni opredelili nacionalno odgovornost za razvoj zdravstvene nege kot znanstvene discipline in kazalnike uresničevanja nacionalne odgovornosti (Skela-Savič, 2017), kar je objavljeno $\mathrm{v}$ tej številki Obzornika zdravstvene nege. Uresničevanje nacionalne odgovornosti za doseganje napredka $\mathrm{v}$ profesionalizaciji zdravstvene nege je ključnega pomena in mora postati prioriteta $\mathrm{v}$ nacionalni strategiji razvoja zdravstvene nege v Sloveniji. Opredeljeno nacionalno odgovornost lahko uresniči odgovoren menedžment, ki ima znanja in sposobnosti za prepoznavanje resursov in priložnosti za doseganje kazalnikov uresničevanja nacionalne odgovornosti. Cilj je profesionalizacija zdravstvene nege za kakovostno, varno in učinkovito zdravstveno obravnavo. Orodja za doseganje cilja so sistematično raziskovanje, strokovna presoja, razvoj kritičnega razmišljanja in odločanje na osnovi dokazov.

Prizadevanja in uveljavljanje raziskovalnega dela $\mathrm{v}$ zdravstveni negi se lahko uresničijo le skozi nacionalni inštitut za raziskave $\mathrm{v}$ zdravstveni negi, katerega ustanoviteljica naj bo Zbornica - Zveza. Čakanje, da bi zdravstveno nego pri tem podprle druge institucije, glede na stanje zdravstvene politike v Sloveniji namreč ni smiselno. Inštitut naj se financira iz članarin članov Zbornice - Zveze in iz prijav na razpise. Skozi tak nacionalni raziskovalni inštitut bo dosežen $» Z$ dokazi podprt« vpliv na politiko, čemur v prihodnosti, ko bo inštitut znanstveno uveljavljen, lahko sledi tudi pridobitev javnih sredstev za delovanje inštituta. Inštitut naj sledi povedanemu $\mathrm{v}$ omenjeni raziskavi: "Središče razvojno-raziskovalnega dela naj bo pacient « (Skela-Savič, 2017).

Stanovska organizacija praznuje 90 let. Nacionalno strokovno združenje Zbornica - Zveza ima pred seboj poseben izziv. Oblikovati mora ambiciozno in sodobno vizijo razvoja, zapisati cilje in strategijo za doseganje le-teh. Jasna vizija razvoja, ki je družbeno odgovorna in je odziv na potrebe družbe, zahteva načrtno razdeljevanje sredstev, premislek o obstoječi organiziranosti in usmeritvi sredstev $\mathrm{v}$ raziskovanje in razvoj. Nujne so zahteve po transparentnem delovanju na ravni organizacije in regijskih društev. Strokovne sekcije morajo postati motor profesionalizacije, spodbujati z dokazi podprto stroko in raziskovalno delo. Na ravni nacionalne organizacije mora biti stroka ločena od politike, ker ji le nestrankarsko delovanje omogoča z dokazi podprto delovanje ne glede na politično opcijo, ki vodi državo. Na drugi strani pa je politična aktivacija zaposlenih $\mathrm{v}$ zdravstveni negi zaželena, vendar naj se le-ta izkazuje preko kandidatur za državne in lokalne volitve.

\section{Zaključna misel}

$\mathrm{Na}$ ravni strokovnjakinje in raziskovalke $\mathrm{v}$ zdravstveni negi in zdravstvu želim sporočiti sledeče: za razvoj zdravstvene nege kot profesije in znanosti postaja pomembno dojemanje zdravstvene nege znotraj poklicne skupine. Obstajata dve dimenziji pogleda nanjo, ki se morata »ujeti«. S tem mislim na znanstveno dimenzijo negovanja in dimenzijo refleksivne prakse nege in skrbi. Znanstvena dimenzija daje visokošolsko izobraženim medicinskim sestram/ 
zdravstvenikom nova znanja, ki naj jih preizkusijo $\mathrm{v}$ praksi. Refleksija na delo v zdravstveni negi pa naj bo raziskovalcem imperativ, da ga znanstveno preverijo in tako uvrstijo ali na področje znanja o negovanju ali nasprotno $\mathrm{v}$ polje $\mathrm{z}$ dokazi nepodprtega delovanja. Pri tem mora vsaka diplomirana medicinska sestra/ zdravstvenik imeti znanja, da lahko razvije sposobnost razumevanja pomena raziskav, rezultat katerih so znanstvena spoznanja, zato naj podpira razvojno delo $\mathrm{v}$ zdravstveni negi in naj prispeva pri soočenju dokazov in spoznanj iz prakse. Tako bo zdravstvena nega ohranila vrednote, ki so jo skozi zgodovino oblikovale v odnosu do zdravega in bolnega človeka, in dodala vrednote znanstvenega spoznanja o negovanju, strokovnega razvoja in $\mathrm{z}$ dokazi podprtega dela. Leto je dober kompromis, da se teorija in praksa zlijeta $\mathrm{v}$ eno. Preplet teh dveh dimenzij bo zdravstveno nego potrdil kot profesijo in znanstveno disciplino, ki »neguje« na osnovi znanstvenih spoznanj. Če tega koraka $\mathrm{v}$ profesionalizaciji visokošolsko izobražene medicinske sestre/zdravstveniki ne bodo naredili, bo zdravstvena nega postala obrobna podporna služba zdravstvenega sistema, ki se bo izgubila $\mathrm{v}$ množici tistih, ki bodo $\mathrm{v}$ vse bolj naraščajočih potrebah po zdravju in obravnavi bolezni, izrabili priložnost postati zagovorniki potreb sodobnega zdravega in bolnega človeka. Zato nimamo časa za neplodne prepire in očitke o pretirani ambicioznosti posameznikov, ki predlagajo spremembe, temveč je treba stopiti skupaj in na znanstveni ravni utemeljiti naše delo, tj. negovanje, kot sta na takratni ravni zahtevnosti in razumevanja stroke to znali že naši predhodnici Florence Nightingale in Angela Boškin.

\section{Literature/Literatura}

Aiken, L.H., Sloane, D., Griffiths, P., Rafferty, A.M., Bruyneel, L., McHugh, M., et al., 2017. Nursing skill mix in European hospitals: cross-sectional study of the association with mortality, patient ratings, and quality of care. BMJ Quality \& Safety, 26(7), pp. 559-568.

https://doi.org/10.1136/bmjqs-2016-005567

PMid:28626086; PMCid:PMC5477662

Albreht, T., 2005. Analiza preskrbljenosti z medicinskimi sestrami ter ovrednotenje stopenjskih ukrepov in projekcij do leta 2033. Ljubljana: Inštitut za varovanje zdravja Republike Slovenije.

American College of Healthcare Executives, 2014. ACHE Healthcare executive competencies assessment tool. Chicago: Healthcare Leadership Alliance, American College of Healthcare Executives.

Carvalho, T., 2014. Changing connections between professionalism and managerialism: a case study of nursing in Portugal. Journal of Professions and Organization, 1(2), pp. 176-190.

https://doi.org/10.1093/jpo/jou004
Directive 2013/55/EU of the European Parliament and of the Council, 2013. Official Journal of the European Union, L354/132. Available at:

http://eur-lex.europa.eu/legal-content/EN/TXT/PDF/?uri=CE LEX:32013L0055\&from=EN [2. 12. 2015].

EFN Workforce Committee, 2014. EFN Matrix on the 4 Categories of the Nursing Care Continuum. Brussels: EFN Workforce Committee.

Horton, K., Tschudin, V. \& Forget, A., 2007. The value of nursing: a literature review. Nursing Ethics, 14(6), pp. 716-740. https://doi.org/10.1177/0969733007082112

PMid:17901183

OECD, 2013. Health at a Glance 2013: OECD Indicators. Paris: OECD Publishing.

https://doi.org/10.1787/health glance-2013-en

Skela-Savič, B., 2016a. Professionalism in nursing: what is its current level in Slovenia? Obzornik zdravstvene nege, 50(1), pp. 4-9.

https://dx.doi.org/10.14528/snr.2016.50.1.94

Skela-Savič, B., 2016b. Razvoj zaposlenih in razvoj celovite kakovosti kot sistemski dimenziji učinkovite zdravstvene obravnave. In: M. Bahun \& B. Pavlenč, eds. 10 let vodenja kakovosti v slovenskem zdravstvu : izkušnje, dobre prakse, ovire: zbornik prispevkov. Jesenice: Splošna bolnišnica, pp. 16-26.

Skela-Savič, B., 2017. Development of nursing professionalization elements in Slovenia: the group interview technique. Obzornik zdravstvene nege, 51(4), pp. 274-297.

https://doi.org/10.14528/snr.2017.51.4.199

Skela-Savič, B., Babnik, K., Trunk Širca, N., Pajnkihar, M., Klemenčič, E., Gabrovec, B., et al., 2017a. Zaključno poročilo cilino raziskovalni projekt: "Zdravstvena nega kot znanstvena disciplina $v$ Sloveniji: mednarodno primerljiv sistem sekundarnega in terciarnega izobraževanja $v$ zdravstveni negi kot temelj raziskav in prispevka znanosti $k$ trajnostnemu družbenemu razvoju": zaključno poročilo ciljno raziskovalnega projekta (CRP). Jesenice, etc.: Fakulteta za zdravstvo Angele Boškin, etc., pp. 1-226.

Skela-Savič, B., Hvalič-Touzery, S. \& Pesjak, K., 2017b. Professional values and competencies as explanatory factors for the use of evidence-based practice in nursing. Journal of advanced nursing, 73(1), pp. 1910-1923.

https://doi.org/10.1111/jan.13280

PMid:28205259

Skela-Savič, B., Pesjak, K. \& Lobe, B., 2016a. Evidence-based practice among nurses in Slovenian hospitals: a national survey. International nursing review, 63(1), pp. 122-131.

https://doi.org/10.1111/inr.12233

PMid:26748610 
Skela-Savič, B., Pesjak, K., Hvalič Touzery, S. \& Dermol, V., 2016b. Predstavitev rezultatov raziskave DP 2.1: Razumevanje potreb po spremembah izobraževanja in raziskovanja $v$ zdravstveni negi - vidik izvajalcev izobraževanja in delodajalcev. Jesenice: Fakulteta za zdravstvo Jesenice, pp. 1-36.

Skela-Savič, B., Pivač, S., Hvalič Touzery, S., Čuk, V., Kalender Smajlović, S., Smodiš, M., et al., 2016c. Prenova srednješolskega modela izobraževanja in razvoj kompetenčnega modela za vse ravni izobraževanja $v$ zdravstveni negi: tehnika skupinskega konsenza : rezultati raziskave DP 3 in DP 4 projekta "Zdravstvena nega kot znanstvena disciplina" (CRP, 2015-2017). Jesenice: Fakulteta za zdravstvo Angele Boškin, pp. 1-33.
Watkins, D., 2011. The influence of master's education on the professional lives of British and German nurses and the further professionalization of nursing. Journal of Advanced Nursing, 67(12), pp. 2605-2614.

https://doi.org/10.1111/j.1365-2648.2011.05698.x PMid:21615461

Cite as/Citirajte kot:

Skela-Savič, B., 2017. Professionalization of nursing in Slovenia: challenges and responsibilities for nurses with a higher education degree. Obzornik zdravstvene nege, 51(4), pp. 264-273. https://doi.org/10.14528/snr.2017.51.4.202 